InOdia $\quad \begin{aligned} & \text { InMedia } \\ & \text { The French Journal of Media Studies }\end{aligned}$

5 | 2014

Media and Diversity

\title{
Elisabeth Staksrud, Children in the Online World. Risk, Regulation, Rights
}

Farnham: Ashgate, 2013, 240 pages

Éric Bruillard

\section{(2) OpenEdition \\ Journals}

Electronic version

URL: http://journals.openedition.org/inmedia/806

DOI: $10.4000 /$ inmedia.806

ISSN: 2259-4728

Publisher

Center for Research on the English-Speaking World (CREW)

Electronic reference

Éric Bruillard, «Elisabeth Staksrud, Children in the Online World. Risk, Regulation, Rights », InMedia [Online], 5 | 2014, Online since 17 October 2014, connection on 24 September 2020. URL : http:// journals.openedition.org/inmedia/806 ; DOI : https://doi.org/10.4000/inmedia.806

This text was automatically generated on 24 September 2020.

(C) InMedia 


\section{Elisabeth Staksrud, Children in the Online World. Risk, Regulation, Rights}

Farnham: Ashgate, 2013, 240 pages

Éric Bruillard

\section{REFERENCES}

Elisabeth Staksrud, Children in the Online World. Risk, Regulation, Rights, Farnham: Ashgate, 2013, 240 pages 
1 This book relies upon several years of research and reviews (notably the European project Kids Online ${ }^{1}$ ). It explores the relationships between the protection of children, risks and rights of information, political and legislative frameworks, the role of NGOs and companies, and restriction... It is a quite informed and well-articulated piece of research, explaining very important issues with a clear discourse. The author's comprehensive argument focuses mainly on five major topics which might be summarized as follows: regulation laws concerning online risks (i.e. the deregulation of traditional prohibiting institutions into counselling and advisory boards), Beck's theory of individualization, the new social role of children, the perception of online risk and

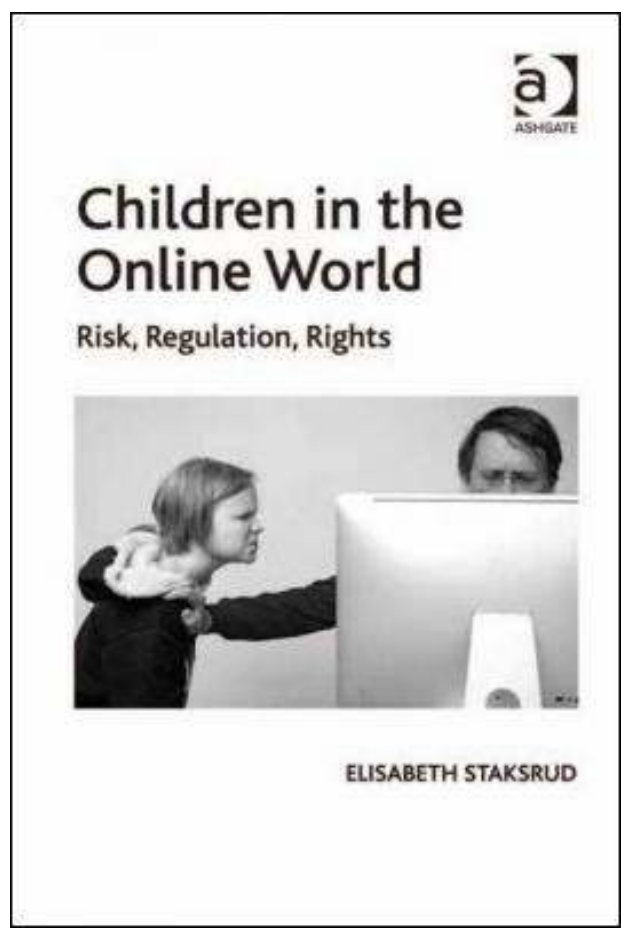
finally the tension which exists online today between citizen and consumer, and the potential implications for children's rights.

One can observe new approaches adopted by European institutions concerning children and online risks. According to Elisabeth Staksrud, they show a shift from authoritative to advisory and can be considered as an outsourcing movement to the industry, to NGOs and to individual users of what were previously government functions and decisions. So, counselling and advising are not only in the hands of the reformed and restructured government bodies, but also the commercial providers and NGOs. Responsibility for child safety online is to a large extent allocated to the service and content providers, such as mobile phone operators, game developers and distributors and social networking services. In these new regulation laws, there is a strong focus on industry-driven solutions such as filtering, classification, hotlines and self-regulation. In this new context, NGOs appear as voluntary organizations, as instruments for implementing policies.

3 There is a classic opposition between prohibition and education. In this change in the "social semantics of law" (85), restrictions are lifted and information and user empowerment are emphasized. There is an explicit reference to user empowerment, as opposed to censorship and prohibition, as the essence of a new and modern institution. In other words, the new policy leaves behind prohibition to promote media competence. But, according to Elisabeth Staksrud, promotion of individual empowerment actually enables the state to roll back its own responsibilities.

4 The problem is to find a good framework to contextualize these new regulation rules and significant insights to discuss their origin and their implications. The great interest of this book is to provide the readers with such meaningful information: a theoretical framework, useful research results and elements of discussion underlying new tendencies. 
5 A way of understanding the debate rests on the theory developed by Beck and BeckGernsheim concerning individualization. Individualization is nowadays imposed on the individual by modern institutions, and at the same time the institutions providing the individual with security and orientation are outsourced.

6 Technological development is a key explanatory factor in the overall Risk Society thesis. In this theory, from distribution of wealth to distribution of risk, this distribution of risk becomes global and independent of, for instance, class and social status. Risk does not derive from conscious choice. Five of Beck's theses can be emphasized:

- risks are open to social definition and construction

- risks undermine the order of national jurisdiction

- there is a commercialization of risk, thus industrial society produces the hazards and the political potential

- knowledge of risk is politically significant

- averting and managing risks can include a reorganization of power and authority

Elisabeth Staksrud applies this theory to the field of media regulation for the protection of children. As research in this domain is mainly quantitative (governmental funding favours quantitative approaches) the book offers a more qualitative view, articulated with Beck's theory. Quite interestingly, the review in the book provides some empirical evidence to Beck's theory and this theory provides interpretative tools for the current situation.

8 The third topic is that of what we now mean by "children". The idea of childhood has changed. According to social constructionism, individual children are seen as social actors in relation to cultural and structural determinants that construct childhood. Following Beck's conclusions, the author provides a very interesting parallel between the changes in women's situation during the last century and the possible changes in the situation of children (for example having money of their own with a privatized paying device, their mobile phones).

9 Research approaches of childhood have also changed and taking into account this view of children as social actors has had a direct impact upon online risks regulation. Elisabeth Staksrud claims that her work is framed by the belief that children are people, that they are individuals in their own rights rather than merely adults-to-be.

10 Being forced to make decisions about potential risks is a distinctive sign of the individualization identified by Beck and Beck-Gernsheim. Indeed, the power gain from technological and economical "progresses" is overshadowed by the production of risk.

11 To have a balanced view (not only a negative one), it is useful to notice that online risk has a positive potential. Some risk is necessary and must be accepted. It is a healthy attitude for risk takers to have had experiences and to have developed self-reflection and self-knowledge. The occurrence of risk increases with age. New features of online risk, often not imagined by parents, are associated with the possibility of the child to no longer be just the potential victim but also the potential predator, creating risk and harm to others.

12 We need to better understand the perception of risks. It can be analyzed through two main categories: extent of damage and probability of occurrence. Some results concerning children (adolescents) are given. They: 1. do not perceive themselves as being invulnerable; 2. overestimate important risks (like HIV) and 3. tend to 
underestimate harmful consequences and long-term effects; 4. exhibit an optimistic bias (they feel themselves to be less at risk than their comparable peers)

To summarize, children are capable of making decisions and the question is not what they know but what they do. Children make risky decisions differently from adults, not because they do not engage in rational calculations but rather because they put too much emphasis on rational calculations. They do not make less rational choices, but less experienced and less informed ones (comparison with adults). Table 5.2 (80) gives very useful implications of neurobiology findings regarding the possible effect of management strategies to minimize children's risk behaviour online. The conclusion is that many strategies might actually be ineffective.

Finally, the author remarks that modern Western societies tend to offer services rather than incentives to action. Quoting Beck, there are only three possible reactions to the experience of an omnipresent risk according to Elisabeth Staksrud: denial, apathy or transformation. In the field of Internet safety, transformation, at least on an institutional level, has become the answer. The question then becomes: is this the right answer? (139)

15 Current public policy is still a belief in rational-choice theory; people will perceive risks and take responsibility for reducing them according to rational calculations.

16 Effective risk management strategies are dependent on understanding how individuals decide to - or not to - engage in respective risk behaviour. Information might be available for individuals (parents), but is it accessible and understandable? As we know, authoritarian, permissive and neglectful parenting styles influence the evaluative and restrictive mediation techniques used by parents, showing significant effects of parenting styles on almost all mediation techniques studied.

17 As established by research, authoritarian public institutions choose to represent themselves as friends in terms of values. But, the self-regulatory approach promoted and supported by the European Commission in many ways puts the safe and secure faith of citizens in the hands of commercial companies. The shift from governmental regulatory institutions to self-regulation by industry also signifies a shift for the user from being a citizen with secured citizen rights to a consumer with a somewhat different set of consumer rights.

18 This also limits the affected people's opportunity to participate in decision-making. The same features that afford democratic rights of participation that also relate to the most problematic risks activating the right to protection. If we are not able or willing to establish a relationship with the product, we have no rights.

Children are individuals in their own right; media technologies are an important source for their knowledge of the world, they can make rational (yet often risky) decisions and have the ability to act as citizens of a nation-state and human beings with human rights. They also have a crucial commercial power.

20 But who advises the children? According to Elisabeth Staksrud, children want privacy and self-sufficiency when using the Internet. Children have more rights in terms of personal decision-making as digital consumers, but at the same time, have lost some of their democratic rights to participate and to be protected as digital citizens.

21 To conclude, Elisabeth Staksrud's book is very useful in shedding light on important contemporary debates and offering keys to understanding them. 


\section{NOTES}

1. http://www.lse.ac.uk/media@lse/research/EUKidsOnline/Home.aspx

\section{AUTHOR}

\section{ÉRIC BRUILLARD}

École normale supérieure de Cachan 